\title{
PENGARUH KOMPETENSI PROFESIONAL GURU PENDIDIKAN AGAMA BUDDHA TERHADAP PRESTASI BELAJAR SISWA BERAGAMA BUDDHA
}

\author{
(Penelitian Dilakukan Pada Guru Agama Buddha di Kabupaten Wonogiri)
}

\author{
Lany Susanti, Hesti Sadtyadi, Anik Tri Kustiani \\ STABN Raden Wijaya Wonogiri
}

\begin{abstract}
Professional competence is teachers ability to master the material that will be presented in depth, and the should understand other material relating to the material to be delivered. Professional competence of teachers is closely related to the learning outcomes that are expected to provide a good learning and achievement for students. This research is a quantitative study, the data collection used questionnaires. Data analysis that is used is a simple linear regression, to determine the extent of the relation ship between the two variables. Based on the results of simple linear regression analysis appear to be any relation ship or influence of teachers professional competence with student learning achievement. Questionnaire tops produce the effect of 0.799 and generate peer influence questionnaire was 0.968, which means that if the professional competence increased by one unit then the coefficient of learning achievement will increase by the influence coefficient with the records of all other variables constant. So there is an influence of the professional competence of teachers of Buddhist education teachers toward on students learning achievement.

Keywords: professional competence, learning achievement
\end{abstract}

\begin{abstract}
ABSTRAK
Kompetensi profesional merupakan kemampuan guru dalam menguasai materi yang akan disampaikan secara mendalam serta memahami materi lain yang berkaitan dengan materi yang akan disampaikan. Kompetensi profesional guru erat kaitannya dengan pembelajaran sehingga diharapkan dapat memberikan hasil dan prestasi belajar yang baik bagi siswa. Penelitian ini merupakan penelitian kuantitatif, pada pengumpulan data mengunakan kuesioner. Analisis data yang digunakan adalah regresi linear sederhana, untuk mengetahui sejauh mana hubungan antara kedua variabel.Berdasarkan hasil analisis regresi linear sederhana tampak adanya hubungan atau pengaruh kompetensi profesional dengan prestasi belajar siswa. Kuesioner atasan menghasilkan pengaruh sebesar 0,799 dan kuesioner teman sejawat menghasilkan pengaruh sebesar 0,968, yang artinya jika kompetensi profesional mengalami kenaikan sebesar satu satuan maka koefisien prestasi belajar akan mengalami kenaikan sebesar koefisien pengaruh tersebut dengan catatan semua variabel lain konstan. Jadi terdapat pengaruh kompetensi profesional guru pendidikan agama Buddha terhadap prestasi belajar siswa.

Kata kunci: Kompetensi profesional, Prestasi belajar
\end{abstract}




\section{PENDAHULUAN}

Pemerintah melakukan beberapa upaya untuk meningkatkan mutu pendidikan tidak hanya sekedar melakukan perubahan kurikulum maupun dengan peningkatan standar kompetensi lulusan, tetapi juga dibutuhkan peningkatan kualitas komponen pembelajaran yang merupakan ujung tombak dalam pembelajaran yaitu guru. Menurut Undang-Undang No.14 tahun pasal 4 tahun 2005 dinyatakan bahwa kedudukan guru sebagai tenaga profesional adalah untuk meningkatkan martabat dan peran guru sebagai inovator dalam pembelajaran yang berfungsi untuk meningkatkan mutu pendidikan nasional. Melalui peningkatan kualitas guru akan berdampak dalam peningkatan kualitas pendidikan. Mengingat pentingnya keberadaan guru dalam proses kegiatan belajar mengajar, maka sudah semestinya kualitas dan kemampuan guru harus diperhatikan. Seorang guru dalam mendidik siswanya harus memiliki beberapa kemampuan dasar, diantaranya adalah kemampuan menyampaikan materi, penguasaan materi pelajaran, kemampuan menyusun strategi pembelajaran serta kemampuan memilih metode dan media yang tepat dalam mengajar (Ihsan, 2005:112-113).

Tuntutan akan keahlian yang dimiliki guru dengan bidang yang diampu sangatlah berpengaruh pada peningkatan kualitas pendidikan dan kualitas lulusan yang dihasilkan. Keselarasan antara keahlian yang dimiliki dengan bidang yang diampu berpengaruh pada kemampuan dan keterampilan guru dalam proses belajar mengajar. Penguasaan materi akan memudahkan guru dalam mengembangkan materi yang disampaikan, dan yang berkaitan dengan materi lain tanpa keluar dari tujuan yang akan dicapai. Selain itu peran guru adalah sebagai sumber belajar bagi siswa, guru mampu menguasai materi dengan baik dan benar-benar berperan sebagai sumber belajar bagi siswanya. Kemampuan yang dimiliki guru tersebut disebut dengan kompetensi profesional. Guru sebagai jabatan profesional, seharusnya menjadi suatu kesadaran dan kewajiban bagi setiap guru. Tetapi pada kenyataannya banyak anggapan bahwa mengajar adalah hal yang mudah, sehingga "ada yang beranggapan setiap orang bisa menjadi guru" (Sanjaya, 2006:14). Hal tersebut menyebabkan kurangnya pemahaman guru akan pentingnya kesesuaian antara keahlian yang dimiliki dengan bidang yang diampu. Sehingga masih ada guru mengampu mata pelajaran yang tidak sesuai dengan keahliannya.

Menurut Pasal 28 ayat (3) butir c tentang Standar Nasional Pendidikan dijelaskan yang dimaksud dengan kompetensi profesional adalah kemampuan penguasaan materi pembelajaran secara luas dan mendalam yang memungkinkan membimbing peserta didik memenuhi standar kompetensi yang ditetapkan dalam Standar Nasional Pendidikan. Kompetensi profesional guru berpengaruh pada prestasi belajar siswa karena dalam pembelajaran guru telah benar-benar memahami materi yang disampaikan, sehingga lebih mudah diterima dan dipahami siswa. Guru yang memiliki kompetensi profesional akan mampu menciptakan pembelajaran yang berkualitas dan menghasilkan prestasi belajar yang baik untuk siswa. Pembelajaran yang berkualitas adalah ketika guru dapat memberikan materi secara baik dan dapat dipahami oleh siswa. Prestasi baik yang dimaksudkan adalah siswa dapat memahami materi yang disampaikan dan mampu mengaktualisasikannya. Prestasi tersebut 
akan terlihat berupa pengetahuan, sikap maupun perbuatan siswa, sehingga siswa memiliki nilai yang baik dari segi kognitif, afektif, maupun psikomotorik.

Kurangnya penguasaan dan sumber belajar mengenai materi yang akan disampaikan sering dijumpai pada proses belajar mengajar. Banyak guru tidak peduli akan tingkat pemahaman siswa pada materi yang disampaikan, guru cenderung menyampaikan materi semampu guru sehingga siswa menjadi tidak paham dan cenderung bingung. Seperti yang diungkapkan oleh salah satu siswa beragama Buddha yang mengatakan bahwa guru pendidikan agama Buddha yang mengampu jika menjelaskan sulit dipahami. Bahkan ketika siswa mengajukan pertanyaan tentang materi yang disampaikan, guru tidak dapat memberikan jawaban atau jawaban yang diberikan berbelit-belit dan tidak sesuai dengan pertanyaan yang diberikan. Menyebabkan siswa kurang memahami materi dan pada saat tes siswa kesulitan mengerjakan (Wawancara dengan salah satu siswa beragama Buddha, tanggal 20 Oktober 2013 pukul 14.00). Hal tersebut menyebabkan prestasi belajar siswa cenderung menurun karena siswa tidak mampu menguasai materi yang diberikan. Siswa akan sulit memahami karena gurunya sendiri tidak menguasai materi yang disampaikan.

Kompetensi guru dituntut untuk terus berkembang begitu juga dengan kompetensi yang dimiliki guru pendidikan agama Buddha yang diharapkan dapat memberikan dampak baik pada prestasi belajar siswa beragama Buddha. Kemampuan yang dimiliki guru berkaitan erat dengan prestasi belajar siswa, guru sangat berperan dalam pembelajaran seperti penyampaian materi dan penguasaan materi yang disampaikan. Prestasi belajar merupakan gambaran dari tingkat kemampuan siswa dari segi kognitif, afektif, dan psikomotorik yang merupakan hasil dari pembelajaran. Melihat kenyataan pada saat ini masih terdapat guru yang mengajar mata pelajaran yang tidak sesuai dengan keahlian dan kemampuan guru tersebut dan tidak memenuhi standar kompetensi guru, pembelajarannya dapat berjalan dengan baik tetapi prestasi belajarnya masih rendah. Sedangkan kompetensi profesional merupakan salah satu kompetensi dari empat kompetensi yang harus dimiliki oleh guru untuk memenuhi standar kualifikasi guru profesional. Guru pendidikan agama Buddha di Wonogiri juga masih ada yang belum memenuhi standar kualifikasi guru profesional yaitu belum memenuhi kompetensi profesional. Kompetensi guru dituntut untuk terus berkembang begitu juga dengan kompetensi yang dimiliki guru pendidikan agama Buddha yang diharapkan dapat memberikan dampak baik pada prestasi belajar siswa beragama Buddha. Kemampuan yang dimiliki guru berkaitan erat dengan prestasi belajar siswa, guru sangat berperan dalam pembelajaran seperti penyampaian materi dan penguasaan materi yang disampaikan. Prestasi belajar merupakan gambaran dari tingkat kemampuan siswa dari segi kognitif, afektif, dan psikomotorik yang merupakan hasil dari pembelajaran.

Prestasi belajar siswa beragama Buddha di Kabupaten Wonogiri cenderung masih rendah karena siswa tidak bisa memahami materi yang diberikan. Prestasi belajar yang rendah tidak hanya berpengaruh pada siswa beragama Buddha saja tetapi juga berdampak pada lulusan beragama Buddha. Lulusan yang beragama Buddha jarang aktif di masyarakat karena kurang percaya diri dan tidak memiliki 
keinginan melanjutkan pendidikannya karena prestasinya cenderung rendah (Wawancara dengan salah satu lulusan beragama Buddha, tanggal 21 September 2013 pukul 16.30). Menurut Mukti (2003:323) pekerjaan guru adalah suatu profesi yang menuntut pengetahuan, keterampilan, dan keahlian tertentu untuk menghasilkan prestasi belajar yang maksimal. Akan tetapi kenyataan di lapangan masih ada prestasi belajar siswa beragama Buddha di Kabupaten Wonogiri yang cenderung rendah walaupun guru yang mengampu sesuai dengan bidang keahliannya. Seperti halnya pendidikan agama Buddha, guru yang mengampu mata pelajaran pendidikan agama Buddha adalah lulusan strata satu pendidikan agama Buddha akan tetapi prestasi belajar siswa yang dihasilkan masih ada yang rendah dan kurang optimal.

\section{PEMBAHASAN}

Proses belajar mengajar merupakan inti dari pendidikan, melalui interaksi edukatif antara guru dengan siswa pada situasi tertentu. Guru memegang peranan utama dalam pembelajaran sebagai tempat aliran nilai-nilai dan ilmu bagi siswa. Penelitian yang dilakukan oleh Sanders menunjukkan bahwa guru memiliki peran besar pada prestasi siswa dan guru lebih berpengaruh dibanding faktor lain, seperti kondisi sekolah ataupun sosial ekonomi siswa (Schater, 2000). Oleh karena itu guru memiliki nilai yang sangat penting dalam pendidikan sehingga guru harus mampu memberikan pembelajaran terbaik bagi siswanya walaupun keadaan siswa memiliki karakteristik yang berbeda-beda termasuk didalamnya cara belajar.
Peningkatan mutu guru sangat diperlukan untuk meningkatkan pengetahuan dan kemampuan yang dimiliki, sebelumnya guru harus melakukan evaluasi. Melalui evaluasi guru dapat mengetahui sejauh mana pengetahuan dan kemampuan yang dimiliki. Guru dapat meningkatkan pengetahuan dan kemampuannya dengan memanfaatkan ilmu pengetahuan dan teknologi yang semakin berkembang pada saat ini. Selain memenuhi persyaratan khusus guru juga harus berkompeten, memiliki kompetensi untuk memenuhi standar kualifikasi profesionalisme guru yang berlaku pada saat ini. Tugas dan tanggung jawab guru sangat kompleks, menurut Fakhrudin (2009:22) menjadi guru memerlukan beberapa persyaratan khusus yaitu (1) menuntut adanya keterampilan yang berdasarkan konsep dan teori ilmu pengetahuan yang mendalam, (2) menekankan pada keahlian bidang sesuai dengan profesi, (3) tingkat pendidikan keguruan yang memadai, (4) kepekaan terhadap dampak kemasyarakatan dari pekerjaan yang dilaksanakan, (5) memungkinkan perkembangan sejalan dengan dinamika kehidupan. Guru yang memenuhi persyaratan khusus tersebut diharapkan mampu melaksanakan tugas dan kewajibannya sebagai pendidik pada pembelajaran maupun di masyarakat dengan baik. Persyaratan khusus tersebut dapat dijadikan dasar dalam peningkatan mutu guru.

Guru dalam melaksanakan tugas dan kewenangan profesinya sebagai pendidik dituntut memiliki kompetensi yang beraneka ragam. Kompetensi yang dimiliki tersebut dapat mendukung guru dalam melaksanakan tugasnya untuk mewujudkan keberhasilan pembelajaran dan tercapainya tujuan pembelajaran. Salah satunya 
adalah kompetensi profesional. Menurut Sumiati dan Asra (2007:243-244) kompetensi profesional merujuk pada kemampuan guru untuk menguasai materi pembelajaran dan memiliki pengetahuan yang luas mengenai subyek yang akan diajarkan. Kompetensi profesional sangat dibutuhkan untuk membentuk guru menjadi guru yang ideal. Guru yang ideal adalah guru yang mengajar materi pelajaran yang menjadi bidang, bakat, dan spesialisasinya jika tidak sesuai maka hasil yang didapatkan tidak baik, siswa merasa tidak puas, dan kualitas anak didik yang dihasilkan sangat rendah (Asmani, 2010 :115). Belajar dan mengajar adalah dua aktivitas yang berlangsung bersamaan dan merupakan inti dari proses pendidikan secara keseluruhan dengan guru sebagai pemegang peran utama sebagai pemberi nilai-nilai intelektual dan religius. Dalam proses belajar mengajar ada tujuan yang akan dicapai, tujuan merupakan cita-cita yang ingin dicapai dari pelaksanaan pembelajaran salah satunya adalah prestasi belajar yang baik. Menurut Dahar dalam Djamarah dan Aswan (2006:2), prestasi adalah segala sesuatu telah dapat diciptakan, hasil kegiatan, hasil yang menyenangkan hati yang diperoleh dengan jalan keuletan kerja. Kegiatan yang terencana dengan baik memungkinkan terlaksana secara sistematis dan membuahkan hasil yang menyenangkan.

Dengan tercapainya tujuan pembelajaran yang telah ditetapkan maka pembelajaran tersebut berhasil dan mendatangkan prestasi yang baik untuk siswa. Azwar (1996:44) menjelaskan prestasi belajar dapat dioperasionalkan dalam bentuk indikatorindikator berupa nilai raport, indeks prestasi studi, angka kelulusan dan predikat keberhasilan. Menurut Fathurohman dan Sutikno (2009:113) ciri-ciri keberhasilan pembelajaran adalah (1) Daya serap terhadap bahan pengajaran yang diajarkan mencapai prestasi tinggi, baik secara individu maupun kelompok, (2) Perilaku yang digariskan dalam tujuan pengajaran khusus (TPK) telah dicapai oleh siswa baik secara individual maupun kelompok, (3) Terjadinya proses pemahaman materi yang secara sekuensial (sequential) mengantarkan materi tahap berikutnya.

Prestasi belajar yang maksimal dapat diperoleh dari hasil belajar yang baik pula, dalam pembelajaran perubahan hasil belajar terjadi dalam aspek kognitif, afektif, dan psikomotorik (Purwanto, 2007:27-28). Penilaian dari masing-masing ranah menggunakan cara dan konteks penilaian yang berbeda-beda. Dalam penilaian ranah kognitif aspek yang dinilai dibedakan menjadi beberapa tipe hasil belajar diantaranya pengetahuan, pemahaman, aplikasi, analisis, sintesis, dan evaluasi. Ranah afektif berkenaan dengan sikap dan perilaku siswa. Persyaratan utama dari pernyataan di atas berkaitan dengan bidang keahlian guru yang berhubungan dengan kompetensi profesional guru. Kualifikasi utama menjadi guru adalah keahlian guru pada bidang yang diampu atau guru harus memenuhi kompetensi profesional. Seperti yang diungkapkan oleh Mukti (2003:323) pekerjaan guru adalah suatu profesi yang menuntut pengetahuan, keterampilan, dan keahlian tertentu untuk menghasilkan prestasi belajar yang maksimal. Akan tetapi kenyataan di lapangan masih ada prestasi belajar siswa beragama Buddha di Kabupaten Wonogiri yang cenderung rendah walaupun guru yang mengampu sesuai dengan bidang keahliannya. Seperti halnya pendidikan agama Buddha, guru yang mengampu mata pelajaran 
pendidikan agama Buddha adalah lulusan strata satu pendidikan agama Buddha akan tetapi prestasi belajar siswa yang dihasilkan masih ada yang rendah dan kurang optimal. Belum diketahui dan tidak jelasnya pengaruh kompetensi profesional terhadap prestasi belajar siswa, maka perlu dilakukan penelitian.

Penelitian ini termasuk pada penelitian kuanntitatif. Penelitian kuantitatif merupakan penelitian yang menekankan pada pengolahan data dengan menggunakan angka-angka dan pengolahan statistik dan struktur dengan menggunakan instrumen-instrumen formal, standar dan bersifat mengukur (Nana Syaodih, 2010:95). Pada penelitian ini untuk mengetahui pengaruh dan sejauh mana pengaruh Kompetensi profesional guru pendidikan agama Buddha terhadap prestasi belajar siswa beragama Buddha. Penelitian ini dilakukan di Kabupaten Wonogiri karena jumlah guru pendidikan agama Buddha di Kabupaten Wonogiri mencukupi untuk digunakan sebagai objek penelitian. Penelitian ini dilakukan kepada guru pendidikan agama Buddha yang tergabung dalam Kelompok Kerja Guru (KKG) dan Musyawarah Guru Mata Pelajaran (MGMP) pendidikan agama Buddha Kabupaten Wonogiri. Alasan lainnya sebagai pendukung yaitu prestasi belajar siswa beragama Buddha di Kabupaten Wonogiri masih rendah, berdampak pada kualitas lulusan yang kurang maksimal. Sedangkan guru pendidikan agama Buddha semuanya lulusan pendidikan agama Buddha yang telah memenuhi kompetensi profesional, karena telah mengampu sesuai dengan bidang profesi kejuruannya.

Penelitian ini dilakukan di Kabupaten Wonogiri karena jumlah guru pendidikan agama Buddha di Kabupaten Wonogiri mencukupi untuk digunakan sebagai objek penelitian. Penelitian ini dilakukan kepada guru pendidikan agama Buddha yang tergabung dalam Kelompok Kerja Guru (KKG) dan Musyawarah Guru Mata Pelajaran (MGMP) pendidikan agama Buddha Kabupaten Wonogiri. Alasan lainnya sebagai pendukung yaitu prestasi belajar siswa beragama Buddha di Kabupaten Wonogiri masih rendah, berdampak pada kualitas lulusan yang kurang maksimal. Sedangkan guru pendidikan agama Buddha semuanya lulusan pendidikan agama Buddha yang telah memenuhi kompetensi profesional, karena telah mengampu sesuai dengan bidang profesi kejuruannya. Memperhatikan keadaan tersebut peneliti ingin mengetahui sejauh mana pengaruh kompetensi profesional guru pendidikan agama Buddha di Kabupaten Wonogiri dengan prestasi belajar siswa beragama Buddha maka penelitian ini dilakukan di Kabupaten Wonogiri. Data diperoleh melalui penyebaran kuesioner, sebelum dilakukan penyebaran kuesioner terlebih dahulu dilakukan uji validitas kemudian setelah itu dilakukan pengisian kuesioner oleh teman sejawat dan kepala sekolah tempat mengajar guru pendidikan agama Buddha yang tergabung dalam Kelompok Kerja Guru (KKG) dan Musyawarah Guru Mata Pelajaran (MGMP) pendidikan agama Buddha di Kabupaten Wonogiri.

Populasi dalam penelitian ini adalah keseluruhan guru pendidikan agama Buddha di Kabupaten Wonogiri yang berjumlah 11 guru pendidikan agama Buddha yang mengampu di 31 sekolah yang terdiri dari 14 sekolah SD, 9 sekolah SMP, 8 sekolah SMA atau setingkatnya. Sampel yang akan diteliti adalah sebagian guru pendidikan agama Buddha yang berjumlah 8 orang guru yang 
mengampu di 17 sekolah yang terdiri dari 11 sekolah SD, 5 sekolah SMP, dan 1 sekolah SMA. Teknik sampling yang digunakan adalah Teknik quota proporsonal random sampling. Dilakukan dengan cara membagi populasi dalam beberapa kelompok dan masing-masing anggota kelompok memiliki peluang yang sama. Setelah dibagi menjadi beberapa kelompok dari masing-masing kelompok selanjutnya diambil sampel penelitian. Objek yang akan diteliti dalam penelitian ini adalah kompetensi profesional guru pendidikan agama Buddha dan subjek penelitian adalah guru pendidikan agama Buddha. Penelitian ini dilakukan dengan menyebar kuesioner pada responden penelitian di masing-masing sekolah. Responden pada penelitian ini adalah 3 teman sejawat dan 1 atasan diambil dari masing-masing sekolah tempat guru pendidikan agama Buddha yang menjadi sampel penelitian mengampu.

Variabel bebas dalam penelitian ini adalah Kompetensi Profesional. Kompetensi profesional menurut Standar Nasional Pendidikan, penjelasan Pasal 28 ayat (3) butir c adalah kemampuan penguasaan materi pembelajaran secara luas dan mendalam yang memungkinkan membimbing peserta didik memenuhi standar kompetensi yang ditetapkan dalam Standar Nasional Pendidikan. Kompetensi profesional yang akan diteliti adalah kompetensi profesional guru pendidikan agama Buddha di Kabupaten Wonogiri. Jumlah guru pendidikan agama Buddha di Kabupaten Wonogiri berjumlah 11 guru yang merupakan populasi penelitian. Guru-guru tersebut mengampu mata pelajaran pendidikan agama Buddha tingkat SD sampai dengan SMA. Pengumpulan data mengenai kompetensi profesional guru pendidikan agama Buddha dengan menggunakan angket dan yang menjadi sampel penelitian adalah 8 guru pendidikan agama Buddha, dengan responden atasan dan teman sejawat. Dalam penilaian terhadap kompetensi profesional guru terdapat beberapa indikator yaitu pemahaman materi, referensi materi atau sumber belajar, pengembangan materi dan pengembangan diri.

Variabel terikat dalam penelitian ini adalah prestasi belajar siswa beragama Buddha di Kabupaten Wonogiri. Prestasi belajar menurut Hamalik (2001: 45) adalah perubahan sikap dan tingkah laku setelah menerima pelajaran atau setelah mempelajari sesuatu. Prestasi belajar yang akan diteliti adalah prestasi belajar siswa beragama Buddha di Kabupaten Wonogiri dari tingkat SD sampai dengan SMA, yang terdiri dari prestasi belajar dari segi kognitif, afektif dan psikomotorik. Responden pada penilaian prestasi belajar siswa beragama Buddha adalah atasan dan teman sejawat atau guru. Kompetensi profesional guru agama Buddha di Kabupaten Wonogiri sebagai variabel bebas dan prestasi belajar siswa beragama Buddha sebagai variabel terikat.

Teknik pengumpulan data yang akan dilakukan sebagai sumber data primer, akan diambil dengan cara sebagai berikut :

1. Wawancara atau mengadakan tanya jawab dengan pihak yang terkait langsung dengan objek penelitian. Dalam hal ini akan dilakukan wawancara secara langsung dengan salah satu guru pendidikan agama Buddha, tokoh masyarakat, siswa beragama Buddha dan lulusan beragama Buddha.

2. Dokumentasi digunakan untuk mengetahui data prestasi belajar siswa beragama Buddha di Kabupaten Wonogiri, dokumentasi data dalam 
penelitian ini adalah fotocopy rapot siswa beragama Buddha.

3. Penyebaran kuesioner atau pengisian daftar pertanyaan mengenai kompetensi profesional dan prestasi belajar yang diajukan secara tertulis oleh peneliti terhadap teman sejawat dan kepala sekolah tempat guru pendidikan agama Buddha mengampu. Penelitian ini menggunakan skala likert, menurut Ating (2006:35) skala likert adalah skala pegukuran yang digunakan untuk mengukur sikap seseorang dengan menempatkan kedudukan sikapnya pada kesatuan perasaan kontinum yang berkisar dari "sangat positif " hingga ke "sangat negatif" terhadap sesuatu (objek psikologis). Pada penelitian ini menggunakan skala likert yang digunakan dengan skor 1 sampai dengan 4. Skor 1 merupakan nilai yang didapatkan jika responden menjawab dengan jawaban "tidak pernah", skor 2 untuk jawaban "kadang-kadang”, skor 3 untuk jawaban "sering" dan skor 4 untuk jawaban "selalu".

Kuesioner pada penelitian ini terdiri dari empat kuesioner yang merupakan jabaran dari masingmasing indikator variabel penelitian. Berikut penjelasan serta jabaran dari masing-masing kuesioner:

a. Kuesioner Kompetensi Profesional

Kuesioner ini digunakan untuk menilai sejauh mana kompetensi profesional yang dimiliki guru pendidikan agama Buddha di Kabupaten Wonogiri. Kuesioner ini dibagikan pada responden di sekolah tempat guru pendidikan agama Buddha mengajar. Responden kuesioner ini adalah atasan dan teman sejawat guru pendidikan agama Buddha. Kuesioner ini dibagi menjadi 2 yaitu kuesioner untuk atasan dan teman sejawat.

\section{Kuesioner Atasan}

Penilaian kompetensi profesional guru salah satunya dilakukan oleh atasan atau kepala sekolah dari masing-masing sekolah. Peneliti melakukan penelitian pada 17 sekolah yang terdiri dari SD, SMP, dan SMA, dengan mengambil sampel 1 atasan dari masingmasing sekolah tempat guru pendidikan agama Buddha mengampu. Kuesioner atasan terdiri dari 10 butir pernyataan yang diambil dari 9 indikator kompetensi profesional.

\section{Kuesioner Teman Sejawat}

Kuesioner teman sejawat di isi oleh teman sejawat guru pendidikan agama Buddha yang dianggap mengetahui secara mendalam mengenai guru pendidikan agama Buddha. Kuesioner teman sejawat disebarkan pada 17 sekolah yang terdiri dari SD, SMP, dan SMA dan merupakan tempat mengajar guru pendidikan agama Buddha. Dari masingmasing sekolah diambil sampel sebanyak 3 teman sejawat, total sampel teman sejawat adalah 51 teman sejawat. Kuesioner teman sejawat kompetensi profesional ini terdiri dari 22 butir pertanyaan yang merupakan jabaran dari 9 indikator kompetensi profesional.

b. Kuesioner Prestasi Belajar Siswa

Prestasi belajar siswa dapat dilihat dari beberapa segi salah satunya adalah penilaian guru terhadap siswa dalam pembelajaran maupun diluar jam pembelajaran. Prestasi belajar terdiri dari tiga komponen yaitu kognitif, afektif dan psikomotorik. Pada penelitian ini peneliti ingin mengetahui prestasi 
belajar siswa beragama Buddha secara keseluruhan dengan menyebar angket kepada kepala sekolah dan teman sejawat guru pendidikan agama Buddha yang mengampu di sekolah. Kuesioner prestasi belajar terdiri dari kuesioner atasan dan kuesioner teman sejawat, berikut penjelasannya:

\section{Kuesioner atasan}

Kuesioner prestasi belajar dengan responden atasan dari masing-masing sekolah yang semuanya berjumlah 17 orang. Kuesioner terdiri dari 10 butir item yang dibuat berdasarkan 8 indikator prestasi belajar. Responden merupakan atasan dari 17 sekolah terdiri dari sekolah SD, SMP, dan SMA yang terdapat guru pendidikan agama Buddha dan siswa yang beragama Buddha.

\section{Kuesioner Teman Sejawat}

Kuesioner penilaian prestasi belajar dengan responden teman sejawat guru pendidikan agama Buddha dari 17 sekolah masing-masing sekolah diambil sampel 3 teman sejawat, jumlah total responden 51 teman sejawat. Kuesioner penilaian prestasi belajar siswa beragama Buddha oleh teman sejawat ini merupakan jabaran dari 8 indikator prestasi belajar menjadi 22 butir pertanyaan.

Untuk menguji kelayakan instrumen pengumpulan data ini dengan menggunakan uji validitas isi dan reliabilitas. Pengujian validitas isi dapat dilakukan dengan meminta pertimbangan ahli dan dengan program SPSS. Uji reliabilitas dilakukan dengan program SPSS. Pengumpulan data melalui lembar kuesioner bertujuan untuk memperoleh informasi dari responden dalam arti laporan pribadi dan hal-hal yang diketahuinya mengenai objek penelitian. Penggunaan lembar kuesioner membutuhkan uji validitas dan reliabilitas lembar kuesioner.

\section{Uji Validitas}

Uji Validitas bertujuan untuk mengetahui tingkat kemampuan instrumen atau tingkat ketepatan instrumen untuk mengukur dan mengungkapkan sesuatu yang menjadi sasaran pokok pengukuran dengan benar dan semestinya. Uji validitas pada penelitian ini dengan menggunakan program SPSS menghitung nilai $r$ hitung dari masing-masing butir pertanyaan. Instrumen dinyatakan valid jika memiliki $r$ hitung lebih besar dari $r$ tabel (Sugiyono, 2007:230). Pada penelitian ini jumlah responden atasan dan teman sejawat berbeda dengan begitu nilai $r$ tabel dari masing-masing kuesioner berbeda.

a. Uji validitas kuesioner penilaian kompetensi profesional guru oleh atasan.

Kuesioner ini digunakan untuk menilai kompetensi profesional guru pendidikan agama Buddha di Kabupaten Wonogiri dengan responden atasan. Responden penelitian pada kuesioner ini berjumlah 17 orang responden atasan dengan 10 butir pertanyaan yang merupakan jabaran dari 8 indikator kompetensi profesional, dengan $r$ tabel 0,482 dan tingkat signifikansi 0,05 . Berdasarkan hasil validitas dengan program SPSS diketahui bahwa semua nilai $r$ hitung > $\mathrm{r}$ tabel maka semua instrumen pada kuesioner penilaian kompetensi profesional guru oleh atasan semuanya valid.

b. Uji validitas instrumen kuesioner penilaian Kompetensi Profesional oleh teman sejawat.

Kuesioner penilaian kompetensi profesional guru pendidikan agama Buddha oleh teman sejawat terdiri dari 22 butir pertanyaan yang merupakan 
jabaran dari 8 indikator kompetensi profesional dengan 51 orang responden. Responden sebanyak 51 orang diambil dari 17 sekolah masing-masing sekolah diambil 3 orang responden teman sejawat. Kuesioner ini digunakan untuk menilai kompetensi profesional guru pendidikan agama Buddha di Kabupaten Wonogiri dengan responden atasan. Responden penelitian pada kuesioner ini berjumlah 17 orang responden atasan dengan 10 butir pertanyaan yang merupakan jabaran dari 8 indikator kompetensi profesional, dengan $\mathrm{r}$ tabel 0,482 dan tingkat signifikansi 0,05. Berdasarkan hasil uji validitas kuesioner penilaian kompetensi profesional oleh responden teman sejawat dengan program SPSS diketahui bahwa semua butir pertanyaan memiliki nilai $\mathrm{r}$ hitung lebih besar dari $\mathrm{r}$ tabel, maka semua butir pertanyaan pada kuesioner penilaian kompetensi profesional guru pendidikan agama Buddha dinyatakan valid dan dapat digunakan.

c. Uji validitas instrumen kuesioner penilaian prestasi belajar siswa oleh atasan.

Kuesioner ini digunakan untuk menilai prestasi belajar siswa beragama Buddha oleh atasan. Kuesioner ini terdiri dari 10 butir pertanyaan dan responden dari kuesioner ini berjumlah 17 orang atasan dari 17 sekolah. Nilai $r$ tabel pada tingkat signifikansi 0,05 adalah 0,482, jika nilai $r$ hitung dari masing-masing instrumen lebih dari nilai $r$ tabel maka instrumen valid. Hasil uji validitas instrumen penilaian prestasi belajar siswa beragama Buddha dengan menggunakan SPSS nilai $r$ hitung dari masing-masing item pertanyaan lebih besar dari nilai $r$ tabel, maka semua instrumen dinyatakan valid dan dapat digunakan. d. Uji validitas instrumen kuesioner penilaian prestasi belajar oleh teman sejawat.

Kuesioner penilaian prestasi belajar siswa beragama Buddha oleh teman sejawat ini terdiri dari 22 butir pertanyaan yang merupakan jabaran dari 8 indikator prestasi belajar. Responden pada penilaian prestasi belajar siswa beragama Buddha oleh teman sejawat ini adalah teman sejawat dari guru pendidikan agama Buddha di masing-masing sekolah. Responden teman sejawat ini diambil dari 17 sekolah masingmasing sekolah diambil 3 orang responden teman sejawat dengan jumlah total 51 orang teman sejawat. Sebelum kuesioner ini disebarkan pada responden terlebih dahulu dilakukan uji validitas instrumen dan instrumen tersebut dinyatakan valid apabila nilai $r$ hitung lebih besar dari nilai $r$ tabel. Hasil uji validitas dengan program SPSS diketahui nilai $r$ hitung semua butir pertanyaan lebih dari r tabel, maka kuesioner ini valid dan dapat digunakan untuk melakukan penelitian.

\section{Uji Reliabilitas}

Instrumen penelitian setelah di uji validitas lalu selanjutnya di uji reliabilitas. Uji reliabilitas bertujuan untuk menunjukkan sejauh mana suatu instrumen dapat memberikan hasil pengukuran yang konsisten jika pengukuran dilakukan berulang-ulang. Uji reliabilitas pada penelitian ini menggunakan program SPSS, jika hasil uji reliabilitas menunjukkan nilai $r$ hitung lebih besar dari $r$ tabel maka instrumen tersebut reliabel (Sugiyono, 2007:190). Nilai r hitung yang dihasilkan dari uji reliabilitas dengan SPSS sangat beragam, dari hasil tersebut tidak hanya untuk melihat reliabel tidaknya suatu instrumen tetapi juga untuk melihat sejauh mana tingkat reliabilitas instrument tersebut. Kategori reliabilitas menurut 
Hilton \& Brownlow (2004:364) ada 4 macam yaitu (a) Nilai $r$ hitung $>0,90$ maka reliabilitas sempurna, (b) Nilai $r$ hitung antara 0,70 - 0,90 maka reliabilitas tinggi, (c) Nilai $r$ hitung 0,50-0,70 maka reliabilitas moderat atau sedang, (d) Nilai $r$ hitung $<0,50$ maka reliabilitas rendah.

Nilai $r$ hitung tiap item $\geq 0,40$ maka item tersebut memiliki reliabilitas konsistensi internal, sedangkan item yang memiliki $r$ hitung $<0,40$ maka item tersebut rendah menurut John dalam Leong \& Austin (2006:144). Semua butir item pernyataan dan pertanyaan pada masing-masing instrument semuanya valid dan reliabel.

a. Uji Reliabilitas instrumen kompetensi profesional guru oleh atasan.

Hasil uji validitas instrumen kompetensi profesional guru oleh atasan semua butir pertanyaan dinyatakan valid, setelah itu dilakukan uji reliabilitas dengan program SPSS. Uji reliabilitas bertujuan untuk mengetahui konsistensi dari instrumen sebagai alat ukur supaya hasil pengukuran dapat dipercaya. Kuesioner penilaian kompetensi profesional guru pendidikan agama Buddha dibuat berdasarkan 9 indikator kompetensi profesional guru menjadi 10 butir pertanyaan. Responden berjumlah 17 orang yang diambil dari 17 sekolah. Hasil uji reliabilitas semua butir pertanyaan memiliki $r$ hitung lebih besar dari r tabel, maka semua butir pertanyaan reliabel. Koefisien $r$ hitung 0,70 - 0,90 maka reliabilitas data termasuk dalam kategori reliabilitas yang tinggi.

b. Uji reliabilitas instrumen kuesioner penilaian kompetensi profesional oleh teman sejawat.

Instrumen kuesioner penilaian kompetensi profesional guru pendidikan agama Buddha terdiri dari 22 butir pertanyaan dan 51 responden.
Responden merupakan teman sejawat dari guru pendidikan agama Buddha, dari masing-masing sekolah tempat guru mengajar diambil 3 responden teman sejawat. Instrumen kuesioner penilaian kompetensi profesional guru pendidikan agama Buddha memiliki nilai $r$ hitung lebih dari $r$ tabel dan semua reliabel. Koefisien nilai $r$ hitung pada instrumen 0,70 - 0,90 maka semua masuk pada kategori reliabilitas tinggi.

c. Uji reliabilitas instrumen kuesioner penilaian prestasi belajar siswa oleh atasan.

Uji reliabilitas instrumen ini menggunakan program SPSS, yang terdiri dari 10 butir pertanyaan yang merupakan jabaran dari 8 indikator prestasi belajar. Responden pada kuesioner penilaian prestasi belajar siswa beragama Buddha adalah atasan dari masing-masing sekolah yang berjumlah 17 responden. Jika nilai $r$ hitung lebih besar dari $r$ tabel maka instrumen reliabel, uji reliabilitas instrumen kuesioner penilaian prestasi belajar siswa oleh atasan dengan menggunakan program SPSS. Hasil uji reliabilitas diatas dapat dilihat bahwa $r$ hitung semua butir pertanyaan melebihi $r$ tabel maka semua butir pertanyaan reliabel. Pada uji reliabilitas instrument ini koefisien reliabilitasnya terbagi menjadi dua kategori yaitu moderat dan tinggi. Kategori tinggi jika nilai $r$ hitung $0,70-0,90$, dan instrumen yang masuk dalam kategori moderat yang meiliki nilai 0,50-0,70.

d. Uji reliabilitas instrumen kuesioner penilaian prestasi belajar oleh teman sejawat.

Uji reliabilitas pada kuesioner penilaian prestasi belajar siswa beragama Buddha oleh teman sejawat terdiri dari 22 butir pertanyaan yang merupakan jabaran dari 8 indikator prestasi belajar. Responden berjumlah 51 responden dari 17 sekolah 
masing-masing sekolah diambil 3 orang sampel teman sejawat. Jika nilai $\mathrm{r}$ hitung lebih besar dari $\mathrm{r}$ tabel maka butir pertanyaan dari kuesioner reliabel dan dapat digunakan. Nilai $r$ hitung dari hasil penghitungan dengan SPSS lebih besar dari $r$ tabel, maka semua butir instrumen reliabel dan dapat digunakan. Koefisien nilai $\mathrm{r}$ hitung dari semua butir item 0,70 - 0,90 semua item masuk pada kategori reliabilitas tinggi.

Model dan analisis data yang akan digunakan dalam penelitian ini adalah regresi. Sebelum dilakukan analisis regresi terlebih dahulu kuesioner di uji normalitas datanya terlebih dahulu, uji normalitas bertujuan untuk mengetahui normal tidaknya suatu distribusi data (Ating\&Sambas,2006:289). Uji normalitas pada penelitian ini dengan One Sample Kolomogorov Smirnov menggunakan program SPSS. Jika data yang di uji belum berdistribusi normal maka dilakukan manipulasi data dengan mentransformasi data menggunakan program SPSS untuk memperoleh data berdistribusi normal (Wahana, 2010:55). Hasil uji normalitas data sudah berdistribusi normal kemudian dilakukan uji t, uji $\mathrm{t}$ pada penelitian ini dengan One sample $t$ test menggunakan program SPSS. Uji t merupakan teknik analisis untuk membandingkan satu variabel bebas. Teknik ini digunakan untuk menguji apakah nilai tertentu berbeda secara signifikan atau tidak dengan rata-rata sebuah sampel dan untuk menguji bagaimana pengaruh variabel bebas terhadap variabel terikat (Usman\&Akbar,2012:140). Kemudian dilakukan uji linearitas dengan tujuan untuk mengetahui apakah dua variabel mempunyai hubungan yang linear atau tidak secara signifikan. Uji ini digunakan sebagai prasyarat dalam analisis korelasi atau regresi linear (Ating\&Sambas,2006:296).

Setelah semua uji telah dilakukan maka dilakukan uji regresi linear sederhana. Analisis regresi digunakan untuk melakukan prediksi (peramalan). Tujuan analisis regresi menurut Ating \& Sambas(2006:243) adalah untuk menentukan model statistik (dalam bentuk formula matematik) yang dapat dipakai untuk memprediksi nilai-nilai variabel terikat atau $Y$ yang dalam penelitian ini merupakan prestasi belajar, berdasarkan nilai-nilai dari variabel bebas atau $X$ merupakan kompetensi profesional guru agama Buddha dengan nilai $(\alpha) 5 \%$. Manfaat dari analisis regresi untuk membuat keputusan apakah naik dan menurunnya variabel dependen dapat dilakukan melalui peningkatan variabel independen atau tidak.

Data pada penelitian ini diperoleh dari hasil kuesioner terhadap responden sebanyak 68 orang, yang terdiri dari 17 orang atasan dan 51 orang teman sejawat. Sampel Responden diambil dari 17 sekolah yang terdapat guru pendidikan agama Buddha, dari masing-masing sekolah diambil responden sebanyak 1 orang atasan dan 3 teman sejawat. Data yang masuk diproses dengan melakukan beberapa uji seelum dilakukan analisis regresi.

\section{Uji Normalitas}

Kuesioner telah di uji validitas dan reliabilitas semua kuesioner valid dan reliabel. Validitas insrumen ditentukan dari nilai $r$ hitung, jika nilai $r$ hitung lebih besar dari $r$ tabel maka instrumen tersebut dinyatakan valid dengan tingkat signifikansi 0,05 . Reliabilitas instrumen juga dilihat dari nilai $r$ hitung lebih besar dari $r$ tabel maka reliabel. Data setelah di uji validitas dan reliabilitas selanjutnya 
dilakukan uji normalitas untuk mengetahui apakah data berdistribusi normal. Pada penelitian ini normalitas yang dilakukan dengan program SPSS uji One Sample Kolomogorov Smirnov. Hasil pengujian normalitas dapat diketahui berdasarkan nilai Asymp. Sig. (2-tailed) dengan membandingkannya dengan nilai signifikansi $\alpha=0,05$. Jika nilai Asymp. Sig. (2tailed) lebih besar dari 0,05 maka data berdistribusi normal. Berdasarkan uji normalitas dengan Kolmogorov-Smirnov Test diperoleh nilai Asymp.sig. pada masing-masing instrument lebih besar dari nilai signifikansi 0,05 maka dapat disimpulkan data pada masing-masing kuesioner berdistribusi normal.

\section{Uji t}

Uji t atau uji parsial digunakan untuk menguji bagaimana pengaruh variabel bebas terhadap variabel terikat. Uji t dilakukan dengan melihat kolom signifikansi pada masing-masing t hitung. Hasil uji t pada masingg-masing kuesioner menghasilkan nilai signifikan $<$ 0,05 maka H0 ditolak dan H1 diterima, yang berarti ada hubungan antara kompetensi profesional guru pendidikan agama Buddha dengan prestasi belajar siswa beragama Buddha. Berdasarkan tabel uji $\mathrm{t}$ penilaian kompetensi profesional dan prestasi belajar oleh atasan diketahui bahwa nilai signifikan ( $p$-value) 0,009 (lebih kecil dari 0,05), maka H0 ditolak yang berarti ada hubungan secara signifikan antara kompetensi profesional guru pendidikan agama Buddha oleh atasan terhadap prestasi belajar siswa oleh atasan. Hasil uji $t$ kuesioner dengan responden teman sejawat menghasilkan nilai signifikan sebesar 0,006 $<0,05$ maka H0 ditolak dan $\mathrm{H} 1$ diterima, yang berarti ada hubungan antara kompetensi profesional guru pendidikan agama Buddha oleh teman sejawat dengan prestasi belajar siswa beragama Buddha oleh teman sejawat.

\section{Uji Linearitas}

Uji linearitas bertujuan untuk melihat apakah hubungan antar variabel itu linear atau tidak. Hubungan yang linear adalah hubungan antar variabel yang akan dianalisis mengikuti garis lurus sehingga jika persamaan regresi dibuat grafik maka akan terbentuk garis yang linear. Uji linearitas pada penelitian ini dengan menggunakan program SPSS, dari hasil uji SPSS pada tabel ANOVA dilihat nilai sig. linearitas dan sig. deviation from linearity lalu dibandingkan dengan tingkat signifikansi $(\alpha)$. Nilai sig. Linearity menunjukkan sejauh mana variabel bebas berbanding tepat digaris lurus, jika nilai sig. linearity lebih kecil dari tingkat signifikansi maka hubungan antar variabel linear. Berdasarkan uji linearitas pada masing-masing kuesioner diketahui bahwa hubungan antar variabel linear. Berdasarkan hasil uji linearitas data kuesioner atasan dengan menggunakan program SPSS diketahui nilai sig. linearity pada tabel adalah sebesar 0,014, jika dibandingkan dengan tingkat signifikansi 0,05 maka nilai sig. linearity lebih kecil dari tingkat signifikansi artinya hubungan antar variabel linear. Hasil uji linearitas data kuesioner teman sejawat menghasilkan nilai sig. linearity 0,000 dibandingkan dengan tingkat signifikansi 0,05 maka nilai sig linearity lebih kecil dari tingkat signifikansi yang artinya hubungan antar variabel linear.

\section{Regresi Linear Sederhana}

Penelitian ini menggunakan analisis regresi linear sederhana untuk mengetahui sejauh mana pengaruh variabel independent terhadap variabel 
dependet. Pada penelitian ini variabel independent adalah kompetensi profesional guru pendidikan agama Buddha dan variabel dependent adalah prestasi belajar siswa beragama Buddha, jadi untuk mengetahui sejauh mana pengaruh dari kedua variabel tersebut. Pengujian regresi linear sederhana pada penelitian ini dengan menggunakan program SPSS. Uji regresi pada penelitian ini ada dua yaitu uji regresi kuesioner atasan dan uji regresi kuesioner teman sejawat. Uji regresi kuesioner atasan bertujuan untuk mengetahui ada tidaknya pengaruh dan sejauh mana pengaruh kompetensi profesioal guru pendidikan agama Buddha terhadap prestasi belajar siswa beragama Buddha berdasarkan penilaian atasan. Berdasarkan hasil uji regresi linear sederhana kuesioner atasan dapat dijelaskan:

1. $R$ Square atau nilai hubungan antara kedua variabel adalah 0,602 yang artinya kompetensi profesional guru pendidikan agama Buddha memberikan kontribusi sebesar 0,602 atau 60,2\% terhadap prestasi belajar siswa beragama Buddha. Artinya 30,8\% prestasi belajar siswa dipengaruhi oleh faktor lain yang tidak terangkum pada analisis (penelitian) ini. $R$ Square merupakan hasil kuadrat dari koefisien korelasi/R $(0,776 \times 0,776=$ 0,602). Nilai Standar eror of the Estimate pada tabel adalah 2,895.

2. Nilai sig .000, artinya nilai tersebut signifikan karena kurang dari 0,05. Karena signifikan maka ada pengaruh antara variabel kompetensi profesional guru pendidikan agama Buddha oleh atasan dan variabel prestasi belajar oleh atasan.

3. Setelah mengetahui adanya pengaruh maka mencari persamaan regresinya, rumus persamaan regresi secara umum persamaan regresi adalah $\mathrm{Y}=$ $a+b$ X, dengan $Y$ merupakan variabel dependent dalam penelitian ini adalah prestasi belajar. Variabel Independent dilambangkan $\mathrm{X}$, pada penelitian ini adalah kompetensi profesional. Sedangkan $\mathrm{a}$ dan $\mathrm{b}$ adalah konstanta yang dicari. Berdasarkan tabel diatas diketahui nilai konstantanya adalah $a=3,721$ dan $b=0,799$. Maka diperoleh persamaan regresinya sebagai berikut $\mathrm{Y}=3,721+0,799 \mathrm{X}$.

4. Berdasarkan hasil perhitungan didapat kesimpulan bahwa kompetensi profesional guru pendidikan agama Buddha memiliki hubungan yang signifikan dengan prestasi belajar siswa beragama Buddha. Hasil uji t (Tabel Coefficients) diperoleh nilai t hitung sebesar 4,763 dan nilai t tabel adalah 1,753. Nilai t hitung > t tabel $(4,763>1,753)$, maka variabel kompetensi profesional guru pendidikan agama Buddha oleh atasan (X) secara parsial memiliki hubungan positif dan signifikan terhadap prestasi belajar siswa beragama Buddha oleh atasan (Y). Hasil uji t sejalan dengan sig $0,000<0,05(\alpha)$ maka memiliki pengaruh yang signifikan.

5. Nilai b sebesar 0,799 merupakan nilai perubahan taksiran variabel $\mathrm{Y}$ secara rata-rata setiap penambahan variabel $X$, semua variabel lain konstan. Artinya bila variabel $\mathrm{X}$ mengalami kenaikan pada satu satuan maka variabel $\mathrm{Y}$ mengalami kenaikan sebesar 0,799.

Uji regresi linear sederhana pada kuesioner teman sejawat bertujuan untuk mengetahui ada tidaknya pengaruh dan sejauh mana pengaruh kompetensi profesioal guru pendidikan agama Buddha terhadap prestasi belajar siswa beragama Buddha berdasarkan penilaian teman sejawat. 
Berdasarkan tabel hasil uji regresi linear sederhana kuesioner teman sejawat diatas dapat dijelaskan:

1. Nilai $R$ Square sebesar 0,924, maka dapat dijelaskan kompetensi profesional guru pendidikan agama Buddha oleh sejawat memberikan kontribusi sebesar 0,924 atau 92,4\% terhadap prestasi belajar siswa beragama Buddha oleh sejawat. Dengan begitu 7,6\% prestasi belajar siswa dipengaruhi oleh faktor lain yang tidak terdapat pada penelitian ini. $R$ Square merupakan hasil kuadrat dari koefisien korelasi/R $(0,961$ x $0,961=0,924)$. Nilai Standar eror of the Estimate pada tabel adalah 2,352 .

2. Nilai sig .000 , artinya nilai tersebut signifikan karena kurang dari 0,05. Karena signifikan maka ada pengaruh antara variabel kompetensi profesional guru pendidikan agama Buddha oleh sejawat dengan variabel prestasi belajar oleh sejawat.

3. Setelah mengetahui adanya pengaruh maka mencari persamaan regresinya, rumus persamaan regresi secara umum persamaan regresi adalah $\mathrm{Y}=$ $\mathrm{a}+\mathrm{b} \mathrm{X}$, dengan $\mathrm{Y}$ merupakan variabel dependent dalam penelitian ini adalah prestasi belajar. Variabel Independent dilambangkan $\mathrm{X}$, pada penelitian ini adalah kompetensi profesional. Sedangkan a dan $\mathrm{b}$ adalah konstanta yang dicari. Berdasarkan tabel diatas diketahui nilai konstantanya adalah $a=1,125$ dan $b=0,968$, maka diperoleh persamaan regresinya sebagai berikut $\mathrm{Y}=1,125+0,968 \mathrm{X}$.

4. Berdasarkan hasil perhitungan didapat kesimpulan bahwa kompetensi profesional guru pendidikan agama Buddha memiliki hubungan yang signifikan dengan prestasi belajar siswa beragama Buddha. Hasil uji t (Tabel Coefficients) diperoleh nilai t hitung sebesar 24,417 dan nilai t tabel adalah 1,677. Nilai t hitung > t tabel $(29,554$ $>1,677$ ), maka variabel kompetensi profesional guru pendidikan agama Buddha oleh atasan (X) secara parsial memiliki hubungan positif dan signifikan terhadap prestasi belajar siswa beragama Buddha oleh atasan (Y). Hasil uji $t$ sejalan dengan sig $0,000<0,05(\alpha)$ maka memiliki pengaruh yang signifikan.

5. Nilai b pada tabel coefficients sebesar 0,968 merupakan nilai perubahan taksiran variabel $\mathrm{Y}$ secara rata-rata setiap penambahan variabel X.

Berdasarkan hasil uji regresi linear sederhana diketahui bahwa kedua kuesioner signifikan dan memiliki pengaruh positif pada variabel dependen. Kuesioner yang signifikan dapat dilihat dari nilai sig pada tabel coefficients, karena nilai sig $<0,05$ maka signifikan atau ada pengaruh variabel Independen atau kompetensi profesional guru pendidikan agama Buddha dengan variabel dependen atau prestasi belajar siswa beragama Buddha. Selain dengan melihat nilai sig bisa juga dengan membandingkan nilai t hitung pada tabel coefficients dengan nilai $\mathrm{t}$ tabel, dari kedua kuesioner memiliki nilai t hitung $>\mathrm{t}$ tabel maka kedua kuesioner signifikan.

Setelah mengetahui bahwa kuesioner tersebut signifikan maka dilihat nilai pengaruh atau besarnya pengaruh kompetensi profesional guru terhadap prestasi belajar, nilai kontribusi dapat dilihat dari nilai $R$ Square pada tabel model summary. Masing-masing kuesioner memiliki nilai kontribusi yang berbedabeda. Kuesioner atasan memiliki nilai $R$ Square 0,602 yang artinya kompetensi profesional guru pendidikan agama Buddha oleh atasan memberikan kontribusi 
sebesar 0,602 atau $60,2 \%$ terhadap prestasi belajar siswa beragama Buddha. Sedangkan 30,8\% prestasi belajar siswa dipengaruhi oleh faktor lain yang tidak terangkum pada analisis ini. Kuesioner teman sejawat memiliki nilai $R$ Square sebesar 0,924, maka kompetensi profesional guru pendidikan agama Buddha oleh sejawat memberikan kontribusi sebesar 0,924 atau $92,4 \%$ terhadap prestasi belajar siswa beragama Buddha oleh sejawat dan $7,6 \%$ prestasi belajar siswa dipengaruhi oleh faktor lain yang tidak terdapat pada penelitian ini.

Tabel coefficients juga digunakan untuk menentukan persamaan regresi dari masing-masing kuesioner. Rumus persamaan regresi secara umum adalah $\mathrm{Y}=\mathrm{a}+\mathrm{b} \mathrm{X}$, dengan $\mathrm{Y}$ merupakan variabel dependent dalam penelitian ini adalah prestasi belajar. Variabel Independent dilambangkan $X$, pada penelitian ini adalah kompetensi profesional. Sedangkan a dan $\mathrm{b}$ adalah konstanta yang dicari. Nilai a adalah terdapat pada tabel cooficients di kolom B bagian atas sedangkan nilai b di kolom B bagian bawah.

Persamaan regresi pada kuesioner atasan nilai konstanta adalah $\mathrm{a}=3,721$ dan $\mathrm{b}=0,799$, maka persamaan regresinya $\mathrm{Y}=3,721+0,799 X$. Nilai $b$ adalah koefisien perubahan taksiran variabel Y secara rata-rata setiap penambahan variabel $\mathrm{X}$. Jika variabel $\mathrm{X}$ mengalami kenaikan pada 1 satuan maka variabel y mengalami kenaikan sebesar 0,799, dengan syarat semua variabel lain konstan. Persamaan regresi pada kuesioner teman sejawat berdasarkan tabel diketahui nilai konstanta $\mathrm{a}=1,125$ dan $\mathrm{b}=0,968$, maka diperoleh persamaan regresi $\mathrm{Y}=1,125+0,968 \mathrm{X}$. Nilai $b=0,968$ merupakan nilai koefisien perubahan nilai variabel $\mathrm{Y}$ setiap variabel $\mathrm{X}$ mengalami perubahan dengan ketentuan semua variabel lain konstan.

\section{KESIMPULAN}

Kompetensi profesional guru pendidikan agama Buddha berpengaruh secara signifikan terhadap prestasi belajar siswa beragama Buddha. Untuk meningkatkan prestasi belajar siswa beragama Buddha di Kabupaten Wonogiri maka perlu dilakukan peningkatan kompetensi profesional guru pendidikan agama Buddha. Pemenuhan dan peningkatan kompetensi profesional guru pendidikan agama Buddha dapat dilakukan oleh beberapa pihak diantaranya oleh guru pendidikan agama Buddha sendiri dengan melakukan evaluasi diri, melakukan penelitian tindakan kelas, mengikuti kegiatankegiatan pengembangan diri seperti seminar, dan memanfaatkan perkembangan teknologi dan iptek untuk menunjang pengembangan diri dan pembelajaran. Guru pendidikan agama Buddha dapat meningkatkan kompetensi yang dimiliki dengan melanjutkan jenjang pendidikan yang lebih tinggi guna meningkatkan prestasi belajar serta memenuhi standar kompetensi profesional guru.

Pengurus KKG dan MGMP agama Buddha di kabupaten Wonogiri harus lebih aktif membuat kegiatan-kegiatan untuk guru pendidikan agama Buddha sekabupaten Wonogiri, kegiatan tersebut dapat memberikan pengetahuan baru, wawasan, serta sarana untuk mengembangkan kemampuan guru pendidikan agama Buddha. Bagi sekolah harus memberikan sarana dan fasilitas bagi guru pendidikan agama Buddha agar dapat digunakan untuk meningkatkan kompetensi yang dimiliki khususnya kompetensi profesional. 


\section{DAFTAR PUSTAKA}

Ihsan, Fuad. (2005). Dasar-dasar Kependidikan. Jakarta : Rineka Cipta.

Leong, F. \& Austin, J. (2006). The Psychology Research Handbook: A Guide for Gradulate Students and Research Assistants. Thousand Oaks: Sage Publications.

Hilton, P. \& Brownlow, C. (2004). SPSS Explained. East Sussex :Routledge.

Fakhrudin. (2009). Menjadi Guru Favorit. Jogjakarta: DIVA Prees.

Asmani, Ma'mur, Jamal. (2010). Tips Menjadi Guru Inspiratif Dan Inovatif. Jogjkarta : DIVA Prees.

Ating \& Sambas. (2006). Aplikasi Statistika dalam Penelitian. Bandung: CV Pustaka Setia.

Mukti, Krisnanda Wijaya. (2003). Wacana Buddha Dhamma. Jakarta: Yayasan Dharma Pembangunan.

Purwanto, Ngalim. (2007). Psikologi Pendidikan. Bandung: PT Remaja Rosdakarya.

Sanjaya, Wina. (2006). Strategi Pembelajaran Berorientasi Standar Pendidikan. Jakarta: Erlangga.

Sugiyono. (2007). Metode Penelitian Administrasi . Bandung: Alfabeta.

Schacter, John. (2000). Teacher Performance-Based Accountability: Why, What and How, Paper, Milken Family Foundation, 1250 Fourth Street, Santa Monica, CA 90401-1353, Ellectronic Papers.

Sumiati \& Asra. (2007). Metode Pembelajaran. Bandung : CV Wacana Prima.

Syaodih, Nana. (2010). Metode Penelitian Pendidikan. Bandung: PT. Remaja Rosdakarya.

Usman, Husaini \& Akbar Setiady, Purnomo. (2012). Pengantar Statistika. Jakarta: PT Bumi Angkasa.

Wahana, computer. (2010). Pengolah Data Statistik Hasil Penelitian Dengan SPSS 17. Yogyakarta: CV ANDI OFFSET. 